\title{
Effect of a program of aerobic exercise accompanying dietary guidance on the rate of obesity and heartbeat for women aged 30-45 years
}

\section{*Dr/ Dalia Al-Sayed Antar ** Dr/ Ashraf Gomaa Shehata} Introduction and problem of research:

The tremendous

technological progress, the economic progress rates and the high standard of living within the family that have taken place in life in all its fields, especially the advancement of equipment and equipment technology, have imposed on us a lifestyle characterized by long sitting periods.

Therefore, our bodies have become abnormal because of our high level of machine use , So if most of the work we do not move only a small part of our muscles has replaced the machine place all what we were doing, we find the replacement of the elevator place of stairs, cars walking place, and appliances and tools used all this led to a lack of movement and dependence on the basic Technology in all aspects of daily life, which led to high rates of weight and obesity, and therefore may be exposed to many diseases that adversely affect the health status of the individual and thus the individual's life in contemporary society, making it a barrier often in carrying out his duty habitually.

And that the lack of movement resulting from the technological development of devices and equipment used in daily life and away from integration in sports programs and physical exercise on a regular basis, individual or collective imbalance in the amount of food intake and the resulting excess calories caused the increase in weight as they will age Adversely affect the individual's physical, psychological and social status and restrict his activity and thus

Instructor in gymnastics, exercises, motor expression and sports shows Faculty of Physical Education, Tanta University

" Assistant Professor of Sports Health Sciences - Department of Sports Health Sciences Faculty of Physical Education in Cairo Al Azhar university

Assiut Journal For Sport Science Arts 
determine the performance of his work in a typical way .

$$
\text { Laila Al-Sibai (2000) }
$$

states that raising physical and physiological efficiency through motor activities contributes to increasing physical fitness, restoring vitality and activity, and also helps the psychological stability of women. (29: 112113)

\section{Farouk Abdul Wahab} (1995), Afaf Shehata and Norhan Hassan (1997) agree that to eliminate excess weight, it is necessary to choose the appropriate type of sports activity, especially in which the body moves all its weight from one place to another. In this regard, we clarify that aerobic exercise is one of the best types of activity Which helps to convert carbohydrate and fatty substances into triadenosine phosphate (ATP), which reduces body fat and leads to weight loss. (26: 18) (23: 13)

Amal Nasr (1994), Ghassan AlZuhairi (1995) and Medhat AlSuweifi (1999) agree that the low cultural awareness of women in the importance of sports activity has led to their lack of exercise and where physical and physiological efficiency begins to decline after the age of 30. (8: 2) (25: 71) (36:
25), which may be associated with the disease.

The importance of this research has been determined in that it deals with obesity as a serious disease that must be treated to reduce the diseases associated with it such as blood pressure diseases, sugar, joints, etc. Also know the types of diets and know if they are true or not. Also discussed were physical curricula that play an important and effective role in oxidation of excess fat As well as regulating the processes of organs and cells of the body,

it is one of the most important factors to prevent obesity and an important part of any approach to maintain or reduce weight has been designed many physical programs and food to reduce the effects resulting from this increase, some of them from the development of food programs only and others put the bar Vol physical sports, including the integration of programs among themselves in order to obtain good results healthy and physically. (31: 9)

The researchers note that there is a problem that is determined by the non-use of diet low-carbohydrate by women at the age of (30-45) 
despite the multiplicity of diet systems, but it is still a traditional problem that requires study and research.

The researchers also noticed that many of the patients at Fit Lap for fitness and slimming who are aged 30-45 suffer from an increase in their weight than the normal rate and the consequent emergence of some diseases such as diabetes, blood pressure, heart disease, atherosclerosis and some Diseases of the locomotor system such as cartilage slide and rough joints and the emergence of symptoms of aging and poor appearance, which affected their psychological and social status. Therefore, the importance of research in how to use exercise in an organized and codified according to scientific scientific principles of health away from randomization and improvisation, especially if accompanied by a diet program codified. In women between the ages of 30-45 to prevent and eliminate as much as possible from some excess centimeters of the body resulting from lack of movement and lack of exercise, so fitness and exercise is one of the areas of primary importance, which is expected to lead to a significant reduction in injury rates Obesity and immobility, as well as nutrition and bad eating habits are used and away from it through the development of a program of integrated aerobic exercises with a program of standardized diet that will help to circulate a kind of health and good health awareness in all areas, especially the physical field

The problem of research has been determined to increase the physical and physiological state of the physical, health and aesthetic condition of the individual, especially for women aged 30-45. Therefore, the researchers considered this problem by developing the aerobic exercise program with a standardized diet program to determine its effect on Some of the body's diameters and heartbeat rates are women aged 30-45 who raise the state of health and the importance of practicing regular exercise and proper nutrition in the community members and women especially at this age.

\section{Research goals}

-Preparation of the aerobic exercise program that matches 
the level of the research sample for women aged 30-45 years

- Preparation of a nutrition program suitable for the level of the research sample for women aged 30-45 years

- Knowing the effect of aerobic exercises associated with the food program in the anthropometric measurements of women aged 30-45 years

- Know the effect of the aerobic exercises associated with the food program in some measures of the heart rate of the women aged 30-45 years.

\section{Research hypotheses:}

There are statistically significant differences between preand post tests in favor of dimensionality in anthropometric measurements (Diameters ) among women aged 30-45 years.

There are statistically significant differences between the tests of preand post and for the benefit of dimension in the measurement of heart rate in the group of women aged (30-45) years.

\section{Search procedures:}

\section{Research Methodology:}

The researchers used the experimental approach using the pre and post measures of one group to suit the nature of the research

\section{The research sample:}

The study sample consisted of (12) women who were selected in a deliberate manner by those who are characterized by obesity according to the indicators of obesity (if the body weight is about $20 \%$ of the normal weight, the person becomes obese with regard to height, body size, sex, age $30-45$

\section{Homogeneity}

and equivalence of the sample Research- :

The homogeneity of the research sample and the equivalence of the variables (age, height, weight) were performed. 
Table (1)

Mean, mean, standard deviation and torsion factor in variables "Age

- Height - Weight" for basic research sample $N=12$

\begin{tabular}{c|c|c|c|c|c}
\hline \hline Variables & $\begin{array}{c}\text { measuring } \\
\text { unit }\end{array}$ & $\mathbf{S}$ & $\begin{array}{c}\text { Media } \\
\text { tor }\end{array}$ & $\pm \mathbf{E}$ & $\begin{array}{c}\text { Torsion } \\
\text { coefficient }\end{array}$ \\
\hline \hline Age & Year & 36.58 & 36.50 & 4.62 & 0.320 \\
\hline Height & $\mathrm{Cm}$ & 160.33 & 160.5 & 3.05 & -0.104 \\
\hline weight & $\mathrm{Kgm}$ & 77.16 & 76.50 & 3.48 & 0.389 \\
\hline \hline
\end{tabular}

Table (1) shows that the torsion coefficients of the study sample were limited to $( \pm 3)$ in the variables (age - height weight) indicating their homogeneity in these variables.

Means and tools for data collection:

1- Devices and tools used in the research:

-Medical balance for weight measurement.

-Restimeter device for measuring length $\mathrm{cm}$.

-Leather measuring tape.

-Blood Pressure Monitor.

-Mat.

-Step.

-Stop Watch.

-Electronic calculator.

-Data registration forms.

Aerobic Aerobic Exercise Program.

\section{A. Program Objective:}

1-Develop a 12-week Aerobic Aerobic Exercise Program and learn about its effect on anthropometric measurements
(Oceans) and on the heart rate of women aged $30-45$ years.

B - Foundations of aerobic aerobic exercise program:

- Graduation of exercises is easier to get harder.

-Fit the exercises for the targeted age range and suit their abilities, abilities and preparations.

-To achieve the objective of the study.

- Taking into account the individual differences among the members of the research sample.

- The program should be flexible.

-Be commensurate with the material and human potential.

-Taking into account security and safety factors.

-Take into consideration the formation of the training load.

- The content should be characterized by diversity and comprehensiveness in the use of exercise to influence some variables and fat ratios.

-Take into account the order of exercises in the program so that 
it facilitates the transition to another, easily and in the shortest time.

-Use of large muscle groups.

-Musical accompaniment to develop a sense of rhythm of movement

\section{Program content:}

(1994) Mohamed Hassan Allawi (1994), Abdel-Moneim Barham and Mohamed Abu Nemra (1994), and Al-Sadiq (1994) (1996), Amal Fouad (1996), Afaf Shehata and Nourhan Soliman (1997), William Kest (1999), Chuck Krautblatt (2000) (2007), Aida Mohammed Hussein (2012), and Maram Mustafa (2013). The researchers conducted a survey questionnaire, which was reviewed by the experts. All the exercises were achieved at a rate of between (85-100\%). The proposed Aerobic Aerobic Exercise Program was developed taking into account the time of each unit, the time of each unit, the target pulse and the inter- ) (16) (8) (33) (20) (9) (6) (23) (44) (45) (28) (7) 37)

\section{The program included:}

-Duration of the program: (12) Twelve weeks.

-Number of units of the program week: (3) three units.

-Total number of units: (36) thirty-six training units.
-Training time: (60) sixty minutes, divided into three parts as follows:

a. Warm-up: (15) Fifteen minutes.

B. The main part: (35) Thirtyfive minutes.

T. Closing (Calming exercises): (10) Ten minutes.

Graduation of the training load was taken into account each week to allow for the purpose of the proposed program.

\section{-Food Program:}

After study and research by the researchers in a large collection of food programs was taken into account that there is a scientific and nutritional means to achieve a healthy diet program does not lead to weight loss, but is linked to physical exercise after the confirmation of the level of health of the participants in the program so exercise Sports is important in weight loss and control, and is not free of any diet of a regular program of exercise,

although regular physical exercise does not burn fat exclusively, but it positively affects the mechanism of the Center for the organization of appetite in the brain. And the owner of the preparation of a special diet program with the program of aerobics and a 
certain percentage of the main components of food from proteins, carbohydrates and fats for the purpose of controlling the calories entering the body The researchers relied on the following bases in the development of the program -The surface area of the body, which is based on the relationship between height and weight, was extracted

-The basic metabolic rate was extracted

-The number of calories needed by the individual has been extracted based on the basic metabolic rate, where the program contains:

A) Different foods that are tasty and suitable for individuals in those ages and lead to a sense of fullness quickly.

B) Foods that are suitable for the individual's standard of living, accessibility and prices.

-The program contains the main nutrients and then determine the number of calories needed by each member of the research sample based on the previous data, which amounted to (19152215) calorie per day for the lowest weight and the highest weight of the sample.

- The number of calories needed by the individual was calculated through activities and exercise (aerobic exercise program).

-Research variables and methods of measurement:

-Name of test: measurement of age.

\section{Test Objective: Age}

Performance description: The laboratory is required to submit an official document for the purpose of confirming the name and date of birth and recording in its form.

--Test Name: Measurement of Length.

\section{Test Objective: Length.}

Performance description: The test stand stands on the base and its back against the upright position, so that the obstacles are adjacent and the laboratory must tighten its body so that it looks forward. The carrier is lowered to touch the upper edge of the head (top point of the skull) Of the holder, which indicates the length of the test in centimeters to the nearest $(0.1 \mathrm{~cm})(34: 16)$ (35: 77).

\section{-Test Name: Weight Measurement:}

\section{Test Objective: Total weight.}

Performance description: The laboratory stands upright on the balance so that it weighs evenly on the feet. The reading on the screen is then taken to the 
nearest $0.50 \mathrm{~g}$ and the weight is recorded in a weight form.

-Measuring the oceans:

A. Shoulder circumference:

It is achieved by passing the measuring tape from the side above the highest point of the muscle groups coated to the shoulders (the two muscles) and from the front with the second rib joint with the shear bone.

B - the abdomen:

The measuring tape is measured at the maximum frontal incontinence of the abdomen.

$\mathrm{C}$ - the vicinity of the buttocks:

Barbed wire is measured at the maximum visible (prominence) level of the backs.

D - thigh circumference:

It includes three main measurements:

D.1- Circumference of the proximal part of the trunk: The measuring tape around the thigh is measured at the top end directly

2- The circumference of the middle part of the thigh: The measuring tape is measured at the level of the right anthropometric marker of the thigh،

The circumference of the distal part of the trunk is known as the circumference of the knee. It is measured by flexing the circumferential ligament around the femur at the proximal level of protrusion above the occipital fold and protrusion of the lateral femoral lobe of the femur.

E) Circumference of the arm (humerus):

The measuring tape around the peritoneal circumference is measured by its right anterroprometric marker, a marker that equates the distance between the lateral extension of the thoracic bone fork and the maximum point located on the humerus bone away from the amerotic mark. It is noted that this diametercan include two measures:

E.1- Measurement of the circumference of the humerus is a fist.

E.2- Measuring the circumference of the humerus is flat.

\section{Experimental experiment}

The researcher conducted the exploratory experiment on 2/6/2016 on 3 participants from the research community who were excluded from the basic experiment. In this experiment, the sample was defined on the physical tests that will be used and the sequence of performance. This experiment promised training for the team: . -Determine the time required for measurements. 
.-Ensure the validity of the devices and tools used.

-Check the efficiency of the helper team

-Know the errors that appear to be avoided when applying the main experiment.

Procedures for implementing the experiment:

PreTests:

Pretests

and

measurements were performed on Fit Lap Fitness and Slimming on $9 / 6 / 2016$ when physical tests were performed.

\section{Execute the search} experiment:

The training curriculum for aerobic exercise accompanied by dietary guidance was implemented in 12/6/2016 until 1/9/2016 for 12 weeks and 3 training units per week. The number of training units reached (36) training units.

-Time of the training unit: (60) minutes guaranteed by warm-up and calm The researchers relied on the principle of gradualism in intensity

-Exercises used: Aerobic exercises of medium intensity. Annex (5)

Post-test:

Post measurements were carried out under the same conditions as the pretests and on 4/9/2015

Statistical Processes:

The researchers used the statistical program (SPSS) to obtain the results of statistical operations.

-SMA.

-standard deviation.

-Torsion coefficient.

-Percentages.

Correlation coefficient.

-Relative weight.

-Relative importance.

-Test the significance of the differences "T" of the measurements.

View and discuss the results:

First. View results

Table (2)

Value ( $T$ ) to find the differences between the mean measurement and the distance measurement of the diameterof objects (humerus) $\mathbf{N}=$

12

\begin{tabular}{l|l|l|l|l|l|l|l}
\hline \hline Variables & Measurement & SMA & $\begin{array}{c}\text { standard } \\
\text { deviation }\end{array}$ & $\begin{array}{c}\text { Average } \\
\text { differences }\end{array}$ & $\begin{array}{c}\text { For } \\
\text { differences }\end{array}$ & $\begin{array}{c}\text { Value } \\
\text { (T) }\end{array}$ & $\begin{array}{c}\text { Level of } \\
\text { significance }\end{array}$ \\
\hline \hline \multirow{2}{*}{$\begin{array}{l}\text { The } \\
\text { humerus }\end{array}$} & Pre & 33.4167 & 2.0207 & -8.08333 & 1.880 & 14.88 & \\
\cline { 2 - 8 } & 25.3333 & 77850. & & & 0.01 \\
\hline \hline
\end{tabular}

The value (t) of the tabular at the level of significance 0.01

Assiut Journal For Sport Science Arts 
It is clear from the results of Table (2) that there are statistically significant differences in the

\section{Table (3)}

circumference of the humerus and in favor of the postmeasurement of the sample in question.

\section{Value (T) to determine the differences between the mean} measurement and the post-measurement of the diameterof objects (shoulder) $\mathrm{N}=12$

\begin{tabular}{l|c|c|c|c|c|c|c}
\hline \hline Variables & Measurement & SMA & $\begin{array}{c}\text { standard } \\
\text { deviation }\end{array}$ & $\begin{array}{c}\text { Average } \\
\text { differences }\end{array}$ & $\begin{array}{c}\text { Standard } \\
\text { deviation } \\
\text { of } \\
\text { differences }\end{array}$ & $\begin{array}{c}\text { Value } \\
\text { (T) }\end{array}$ & $\begin{array}{c}\text { Level of } \\
\text { significance }\end{array}$ \\
\hline \hline \multirow{2}{*}{$\begin{array}{l}\text { the } \\
\text { shoulder }\end{array}$} & Pre & 110.000 & 26.5706 & \multirow{2}{*}{-9.1666} & 1.399 & 13.04 & 0.01 \\
\cline { 2 - 7 } & Post & 119.166 & 8.63222 & & & \\
\hline \hline
\end{tabular}

The value ( $\mathrm{t}$ ) of the tabular at the level of significance 0.01

It is clear from the results of

Table (3) that there are statistically

differences significant in the circumference of the shoulder and in favor of the telemetry of the sample in question

Table (4)

Value ( $T$ ) to determine the differences between the mean and premeasurements of the bodies (hip and thigh $(\mathrm{N}=12)$

\begin{tabular}{|c|c|c|c|c|c|c|c|}
\hline Variables & Measurement & SMA & $\begin{array}{c}\text { standard } \\
\text { deviation }\end{array}$ & $\begin{array}{c}\text { Average } \\
\text { differences }\end{array}$ & $\begin{array}{c}\text { Standard } \\
\text { deviation } \\
\text { of } \\
\text { differences }\end{array}$ & $\begin{array}{l}\text { Value } \\
\text { (T) }\end{array}$ & $\begin{array}{l}\text { Level of } \\
\text { significance }\end{array}$ \\
\hline \multirow[t]{2}{*}{ Thigh } & Pre & 67.1667 & 1.95982 & \multirow[t]{2}{*}{13.9166} & \multirow[t]{2}{*}{1.831} & \multirow[t]{2}{*}{26.31} & \multirow[t]{2}{*}{0.01} \\
\hline & Post & 53.2500 & 2.82307 & & & & \\
\hline \multirow[t]{2}{*}{ Hip } & Pre & 116.000 & 1.85864 & \multirow[t]{2}{*}{14.583} & \multirow[t]{2}{*}{2.644} & \multirow[t]{2}{*}{19.10} & \multirow[t]{2}{*}{0.01} \\
\hline & Post & 101.416 & 2.35327 & & & & \\
\hline
\end{tabular}

The value $(\mathrm{t})$ of the tabular at the level of significance 0.01

The results of Table (4) show and femoral circumference and that there are statistically in favor of post-measurement significant differences in hip of the sample in question. 
Table (5)

The value of ( $T$ ) to find the differences between the average of the premeasurement and the distance measurement of the diameter of objects (abdomen) $\mathrm{N}=12$

\begin{tabular}{l|l|l|l|l|l|l|l}
\hline \hline Variables & Measurement & SMA & $\begin{array}{c}\text { standard } \\
\text { deviation }\end{array}$ & $\begin{array}{c}\text { Average } \\
\text { differences }\end{array}$ & $\begin{array}{c}\text { Standard } \\
\text { deviation } \\
\text { of } \\
\text { differences }\end{array}$ & $\begin{array}{c}\text { Value } \\
(\mathrm{T})\end{array}$ & $\begin{array}{c}\text { Level of } \\
\text { significance }\end{array}$ \\
\hline \hline Belly & Pre & 122.250 & 2.56285 & 19.0833 & 2.678 & 24.68 & 0.01 \\
\cline { 2 - 6 } & Post & 103.166 & 1.64225 & & & \\
\hline \hline
\end{tabular}

The value $(\mathrm{t})$ of the tabular at the level of significance 0.01 The results of Table (5) show statistically significant differences in the abdomen and for the postmeasurement of the sample in Table (6)

Value (T) to determine the differences between the mean measurement and the post weight measurement $\mathrm{N}=12$

\begin{tabular}{c|c|c|c|c|c|c|c}
\hline \hline Variables & Measurement & SMA & $\begin{array}{c}\text { standard } \\
\text { deviation }\end{array}$ & $\begin{array}{c}\text { Average } \\
\text { differences }\end{array}$ & $\begin{array}{c}\text { Standard } \\
\text { deviation } \\
\text { of } \\
\text { differences }\end{array}$ & $\begin{array}{c}\text { Value } \\
\text { (T) }\end{array}$ & $\begin{array}{c}\text { Level of } \\
\text { significance }\end{array}$ \\
\hline \hline \multirow{2}{*}{ weight } & Pre & 77.166 & 3.48590 & 14.25000 & 1.28806 & 38.32 & 0.01 \\
\cline { 2 - 5 } & post & 58.916 & 3.55370 & & & & \\
\hline \hline
\end{tabular}

The value ( $\mathrm{t}$ ) of the tabular at the level of significance 0.01

The results of Table (6) show that there are statistically significant differences in the

\section{Table (7)}

The value of $(t)$ to determine the differences between the intermediate measurement and the post-measurement of the pulse $\mathbf{N}=\mathbf{1 2}$

\begin{tabular}{l|l|l|l|l|l|l|l}
\hline \hline Variables & Measurement & SMA & $\begin{array}{c}\text { standard } \\
\text { deviation }\end{array}$ & $\begin{array}{c}\text { Average } \\
\text { differences }\end{array}$ & $\begin{array}{c}\text { Standard } \\
\text { deviation } \\
\text { of } \\
\text { differences }\end{array}$ & $\begin{array}{c}\text { Value } \\
(\mathbf{T})\end{array}$ & $\begin{array}{c}\text { Level of } \\
\text { significance }\end{array}$ \\
\hline \hline Pulse & Pre & 70.1667 & 1.58592 & 7.50000 & 1.00000 & 25.98 & 0.01 \\
\cline { 2 - 4 } & Post & 62.666 & 1.72328 & & & & \\
\hline \hline
\end{tabular}

The value ( $\mathrm{t}$ ) of the tabular at the level of significance 0.01 
It is clear from the results of Table (7) that there are statistically significant differences in the pulse rate and for the benefit of the telemetry of the sample in question.

\section{Second. Discussion of results}

The results of the tables $(2,3,4,6,6)$ indicate that there are significant differences between the preand post measurements and for the measurements of the dimension in the measurements of the diameterand pulse rate and weight, and the researchers believe that the emergence of these differences in the general diameterof the body due to the impact of the body's diameters the program.

Bob et al., 2000, emphasizes that aerobic exercises that exercise regularly and for a long time increase energy consumption, leading to decreased body fat So as to ensure the consistency of these oceans. (43)

Because the return of regular exercise reduces fat tissue around the muscle fibers, the lack of peripheral measurements, body mass index, weight and fat ratio is due to lack of fatty tissue and is often more than the increase in the size of muscle mass. This may be due to the impact of the aerobic training program associated with dietary guidance, which is consistent with the results of previous studies such as the study of Muhammad Khalil (1993), Amal Nasr (1994) (19), "Aida Sherif" (2012) (19), "Aisha Sherif" (2007)

Which showed improvement in weight loss physical measurements (oceans) and reduce body fat. We find that the index of the low rate of body circumference of the members of the research sample shows a clear decrease through the use of the program, which codified scientifically, which led to a gradual increase in muscle mass and when increasing the fat-free tissue increases the mitochondrial base of the energy penetrates even greater than the sitting position, Fat. In general, the aerobic exercise associated with a diet program was effective as well as controlling the calorie intake that had a role in the process of deficiency, ie the number of calories entering the body by determining the calories in terms of style The burning of calories through the exercise of stomach all led to a shortage of calories necessary for physical performance and led to the use of muscle to take their 
energy of stored fat, and agrees with studies where it considers that the best ways to reduce fat from the body is the way the joint program of sport and organization Food (1) (30) (43) (42)

The validity of the first research, which states: There are statistically significant differences between the preand post tests for the benefit of dimensionality in anthropometric measurements (oceans) among women aged 30-45 years

We find through the results of Table (7) and what was presented and analyzed for the results of functional tests. It is clear to us that the heart rate tests before and after the application of the program showed a significant difference between the pre-test and the post-test and the post-test. The researchers attributed the reason for these differences and the noticeable improvement to the effect of the aerobic training program accompanying the dietary guidance. This is consistent with what Abu Al(1990), Lambert (1994) and Aweys al-Jabali (2000) indicate that the pulse rate is the primary determinant to be observed in the exercise of sports, in which the types of physical pregnancy vary And leads to functional changes and that each activity of a practicing athlete impact Which enhances the health efficiency to meet the functional requirements of the physical activity and the physical abilities and high levels of physical activity in any activity is a reflection of the enjoyment of these individuals and practitioners of high functional capabilities, which must be taken into account in the exercise of various sports activities according to the programs developed and lead to Functional changes in the biological organs of the body and pulse rate of the heart beat are the most important of these basic functional determinants, which confirms the results of the research in improving the pulse rate. (3) (10) (41) (24) The researchers attributed this difference to the adjustment in the heart rate due to regular responses obtained through the regularity of the physical and dietary method, which required the heart to pump blood according to the need of the muscles of the body during the exercise of muscle, resulting in an increase in heart capacity accompanied by low heart rate 
During rest, and this fact demonstrates the success of the approach to improving heart fitness and health. The heart rate is an objective physiological criterion, and a true indication of the intensity of the effort and the degree of adaptation

. The validity of the first research, which states: There are statistically significant differences between the tests of preand post and for the benefit of dimension in the measurement of heart rate in the group of women aged 30-45 years

\section{Conclusions}

and

recommendations:

First: Conclusions

Through the results reached it can be concluded as follows:

1- The use of aerobic exercise and diet program for women aged (30-45) years helped to get rid of excess weight (obesity)

2-The training program for women of the age of (30-45) years has had a positive effect in the elimination of fat in areas (abdomen, shoulder, humerus, hip, thigh.

3-The food program, which was used with the scrutiny of all its food contents and components made their application easy in the research sample, and can be followed by everyone.
4-There is an improvement in the measurements and functional tests in the research sample and show this through the differences in the moral rate of heart rate

\section{Second: Recommendations}

In light of the results of the results, the two researchers were able to recommend the following:

1-the need to rely on the program prepared, which affected some of the body's surroundings and weight and pulse rate

2-The program can be used training aerobic exercise and nutrition to know and measure the physical indicators (body composition) and its variables, for the purpose of study.

3-The responsible authorities in the State to pay attention to this aspect by opening health fitness centers in each neighborhood (funding of youth in the establishment of health centers

4-Health awareness through the audio and visual media in television stations and radio teaching and guidance of citizens to the habits of healthy food and the importance of exercise of any kind and the adoption of the physical program and low-carbohydrate diet in weight reduction 
according to instructions in the research board.

5-Age studies and other types of nutrition-supported physical programs studied when weight loss and health maintenance

6-Conduct similar studies on different age groups for both sexes

\section{References}

1-Abu El-Ela Ahmed AbdelFattah and Ahmed Nasr ElDin Sayed (2003): physiology of fitness, Dar Al-Fikr AlArabi, Cairo,

2-Abul-Ela Ahmed AbdelFattah, Ahmed Omar ElRouby (1986): Selection of the talented in the field of sports, book publishing house, Cairo

3-Abdel Moneim Suleiman Barham, Mohamed Khamis Abu Nemra (1995): Encyclopedia of Exercise, I 2, Dar Al Fikr for printing, publishing and distribution.

4- Afaf Abdel-Moneim Shehata, Nurhan Soliman Ahmed (1997): The Scientific and Practical Basis for the Use of the Step-by-Step Training Fund, Knowledge Facility, Alexandria.

5-Aida Mohamed Sherif (2013): Effect of aerobic exercise program on massage on weight loss and functional efficiency in obese women, unpublished master thesis, Faculty of Physical Education, Tanta University

\section{6-Amal Fouad Said (1996):}

Influence of a proposed aerobic program for weight loss on the concentration of transaminase enzymes, hydrolyzed enzyme and blood lipids a unpublished $\mathrm{PhD}$ thesis, Faculty of Physical Education for Girls, Cairo, Helwan University.

7- Amal Fouad Said (2003): A follow-up study on the effect of aerobic exercise on the increase of high density lipoproteins and reduction of low density lipoproteins in the blood as a major factor in the prevention of heart disease for both sexes, unpublished $\mathrm{PhD}$ thesis, Faculty of Physical Education for Boys, Helwan University.

8- Amal Nasr Mohamed ElToukhi (1994): Effect of a proposed exercise program on improving the physical efficiency and fat ratio of housewives, unpublished master thesis, Faculty of Physical Education for Girls, Cairo, Helwan University, 1994.

9-Attiyat

Mohammed

Khattab, Maha Mohamed Fikri, Shahira Abdel Wahab Choucair 
Fundamentals of Exercise and rhythmic exercises, book center for publishing, Cairo

10- Aweys Al-Jabali (2000): physical Training Theory and Practice", Dar Al-Tayseer, Cairo

\section{1- Azza Fouad Mohamed} Shoura (1991) Effect of a gradual aerobic exercise program on the severity of some morphological variables, physical efficiency and level of blood cholesterol concentration for women in the United Arab Emirates, Scientific Conference "Future Vision for the Physical Education of Teachers", vol. 2, Helwan University.

\section{2- Bahaa Eddin Ibrahim} Salameh (1990): The effect of high-intensity and lowintensity physical training on body weight, body fat, cholesterol, high density and low density lipoprotein, published research, Scientific Journal of Sports Education and Sports, p. 807, Helwan University.

\section{3- Bahaa El Din Salameh} (1994): Physiology of Sport, II, Dar Al-Fikr Al-Arabi, Cairo.

14- Bob D ,Ros B. Jan R . Dennis $R$ (2000). Physical Education and study of sport 4ed, Harourt .Publishers
,Douglas H .Richie ,J.R Aerobic

15- College of Physical Education of America (1997): The effect of low weight as a result of aerobic exercise on the risk factors cause coronary heart disease on men with the fat style.

16- Danse injuries, the physician and sports medicine A.Mcraw - hill publication a sultan web jeer an. Com/ leaqh. $\mathrm{Htm}$

17- Diane Dahm, Jay Smith (2006): Fitness for all Mayo Clinic, Arab Science House.

18- Eileen Wadie Faraj (1996): Experiences in games for young and old, Faculty of Physical Education for Girls, Alexandria University.

19- Farouk Abdel Wahab (1995): Sports Health and Fitness, Dar Al-Sharq, Cairo.

\section{0- Fatima Saad Abdel}

Fattah (2003): Effect of proposed training program on blood fat and physical building components and some physiological variables in the students of the Faculty of Physical Education Tanta University, Journal of the Faculty of Physical Education, Tanta University, p. 32, vol.

\section{1- Ghassan Al-Zuhairi} (1995): 
Publications for Distribution, Lebanon

\section{2- Hanaa Mohamed Farid} (2000): Effect of a proposed sports program on the level of physical fitness and weight loss for women, unpublished master thesis, Faculty of Physical Education for girls in Cairo Helwan University

\section{3- Hashem Adnan Al-Kilani} (2000): physiological foundations of sports training, Al-Falah Library for Publishing and Distribution, Kuwait

24- Hussein Dashti Diet for the treatment of diseases related to obesity, Al - Ajiri Library, Kuwait.

\section{5- Ibrahim Ahmed Salam} (2000 AD): The Applied Approach of Physical Education in Physical Education!

26- Lambert,M.Ietal (1994): Heart Rate During training and competition for long distance running, journal of sports, special Lssue, vol (16) London, P.P 685- 690

27- Laila Sibai (2000): Diseases of Malnutrition, Knowledge Establishment, Alexandria

28- Laila El Sayed Farhan (2001): Measurement and
Testing in Physical Education, Amoun Press, Cairo

29- Lin Goldberg, Dayan L. Elliott, [Arabization] Mohammed Samir Al-Atai (2002): The Effect of Exercise in Recovery, Obeikan Library

30- Maram Mustafa Eid (2013): Effect of aerobic exercises with sage on the thermal endowments and some physiological characteristics of women with postmenopausal women, unpublished master thesis, Faculty of Physical Education,

Mansoura University.

\section{1- Medhat Al-Suweifi} (1999): The dangers of cholesterol, translation of the Arab Center, Dar Al-Ulum Saudi Arabia, 1999.

\section{2- Mohamed Ahmed Khalil} (1993): Study of an aerobic training program to control the weight of the efficiency of lung functions and the level of concentration of some blood serum, published research, Journal of theories and applications, Faculty of Physical Education for Boys, Alexandria University

33- Mohammed Hassan Allawi (1994): the science of sports training, 2, Dar Al Ma'arif, Cairo 
34- Mohamed Subhi Hassanein (2005): Evaluation and Measurement in Physical Education, C2, Dar Al-Fikr AlArabi, Cairo, 2005

35- Mohamed Nasr El-Din Radwan (2003): Reference in physical measurements, Dar Al-Fikr Al-Arabi, Cairo, 2003. 36- Nemat Ahmed Abdul Rahman (2000): Aerial activities, Knowledge facility, Alexandria.

37- Osama Kamel Rateb (2000): Relationship of the ratio of fat and its variation to some physiological variables related to physical exertion in children, unpublished $\mathrm{PhD}$ thesis, Faculty of Physical Education, University of Baghdad.

38- Osama Kamel Rateb): 2004) Physical Activity and Relaxation, Arab Thought House, Cairo.

39- Rasha Mustafa Farid (2002): Effect of a proposed motor program on the efficiency of the circulatory and respiratory system for women, unpublished doctoral thesis, Faculty of Physical Education for Girls, Cairo, Helwan University.

40-Robert Johnson (1996): How to conquer cholesterol, translation of the Center for Arabization, Arab Science House, Lebanon
41- Salwa Abdelhadi Shakib (1993): A proposed exercise program and its impact on some physiological and psychological variables and the level of performance of the daily motor activities of older people, Scientific Journal of Physical Education and Sport in the Arab World, Faculty of Physical Education for Boys in Haram, Vol.

\section{2- Salwa Abdelhadi Shakib} (2007) Effect of Aerobic Exercise on Fat Fat for Weight Loss of Women, Unpublished Master Thesis, Faculty of Physical Education, Tanta University

\section{3- Salwa Abdelhadi Shakib} (2003) Effect of some sports activities on some physiological responses to leptin hormone and some blood variables, unpublished master thesis, Faculty of Physical Education, Tanta University.

44- William B. Kest (1999): Effects Of Aerobic training and Gender on HLD-C and LDL-C subtraction in Yucatan Minature Swine . Amer .Soc. of exercise Phys, Vol. 2:2

45- Chuck Krautblat (2000): Fitness Training Manual. American College Of Sports Medicine (ACSM) Copyright By IFA 